\title{
Open data and public health
}

\author{
Marcelo D'Agostino, ${ }^{1}$ Noah O. Samuel, ${ }^{2}$ Maria Janina Sarol, ${ }^{2}$ Federico G. de \\ Cosio, ${ }^{1}$ Myrna Marti, ${ }^{1}$ Tianyu Luo, ${ }^{3}$ lan Brooks, ${ }^{2}$ and Marcos Espinal ${ }^{1}$
}

Suggested citation D'Agostino M, Samuel NO, Sarol MJ, de Cosio FG, Marti M, Luo T, et al. Open data and public health. Rev Panam Salud Publica. 2018;42:e66. https://doi.org/10.26633/RPSP.2018.66

\begin{abstract}
This article provides an overview of the intersection of open data and public health by first defining open government data, public health data, and other key concepts and relevant terminologies. There are differing perceptions on the urgency and importance of the openness of public health data. It has been established that disease outbreaks such as happened during the Ebola and Zika virus epidemics are indicative of the need for countries to develop a framework that will provide guidance for the management of public health data. Such a framework should ensure that data collected during public health emergencies are accessible to the appropriate authorities and in a form that can help with timely decision-making during such public health crises. In this article, we highlight available open data policies across many countries, including in the Americas. Our analysis shows that there are currently no articulated policy guidelines for the collection and management of public health data across many countries, especially in Latin America. We propose that any national data governance strategy must address potential benefits, possible risks, examples of data that could be shared, and the attributes of such data. Finally, we stress that the key concern in the Americas should be the development of regional frameworks for open data in public health that can be adopted or adapted by each country through appropriate national or subnational policies and strategies.
\end{abstract}

Keywords Information systems; data sources; public health; health systems; confidentiality.

In this article, we provide some basics about open data and open health data in particular, and we discuss how these concepts apply to the public health sector. Open data as a concept is widely applicable in various sectors, and its importance has been articulated in the extant literature. Governments around the world are already creating policies to enhance data openness by providing detailed descriptions of how data relating to public welfare should be managed. There is growing emphasis on making these data available to the

\footnotetext{
Pan American Health Organization, Washington, D.C., United States of America. Send correspondence to Marcelo D'Agostino, at dagostim@paho.org
}

public for free, and in formats that allow a variety of uses.

"Open data" is a general umbrella term that is used to describe all forms of data made available to the public for free. Public health data should be included in this category. Unlike personal health data (whose improper release might violate an individual's privacy), public health data are often aggregated information that can help in making decisions regarding health issues. The advantages and benefits that can accrue from having appropriate data on which

\footnotetext{
School of Information Sciences, University of Illinois at Urbana-Champaign, Champaign, Illinois, United States of America.
}

to base decisions point to the need for open public health data.

Documented and openly shared public health data can help to prevent catastrophic events. Such data can also help health researchers and, by extension, enhance the health of a city, a state, a nation, or the world at large.

The drive for data openness is gaining impetus in various quarters. For example, the concept of openness has built noticeable strength within the technology environment, with a focus on open source application development and

\footnotetext{
School of Information Studies, Syracuse University, Syracuse, New York, United States of America.
} 
code sharing. The scientific community has also been pushing for open access to scholarly work, and a few initiatives have been launched in the past few years to support this (1). In addition, government agencies around the world are creating policies to enhance access and use of government data by the public at large (2).

In the research literature, there are different viewpoints on the urgency and the importance of the concept of openness of public health data. For example, it has been established that disease outbreaks such as happened during the Ebola and Zika virus epidemics are indicative of the need for countries to develop a framework that will provide guidance for managing public health data. Such frameworks should ensure that data collected during public health emergencies are accessible to the appropriate authorities and in a form that can help with timely decision-making during such public health crises. Carney and Weber (3) have stated that "today's public health crises, as exemplified by the Ebola outbreak, lead to dramatic calls to action that typically include improved electronic monitoring systems to better prepare for, and respond to, similar occurrences in the future." Having data-driven public health intelligence-gathering is only possible if the required data are available and are being shared.

Vest and Issel (4) have asserted that there is a need for improved information system capabilities in public health agencies and that these capabilities may be the key to those agencies remaining relevant in evolving health care systems. There are also increased calls for integrating public health surveillance data within health departments. The cost efficiency of such an approach to the coordination of care can be striking (5). In managing public health data, various factors across different agencies have been considered. According to Nguyen (6), one of these factors in relation to public health data on child maltreatment is "interoperability," which could be a synonym for openness (6).

In the remainder of this literature review, we provide an overview of the intersection of open data and public health by first defining and discussing open government data (OGD), public health data, and other key concepts and terminologies.

\section{KEY CONCEPTS AND TERMINOLOGIES}

\section{Open data}

Although the term "open data" seems intuitive and self-explanatory, individuals and organizations may have different conception of openness. Some concepts and principles relevant to some sectors may not apply to other sectors. For instance, the Project Open Data of the Government of the United States of America states that open data must be managed after being released (7). This principle applies to academic research projects, but they are usually only required to keep the data for a few years after the end of the project.

A widely used definition of open data is the Open Definition, which states that "open data and content can be freely used, modified, and shared by anyone for any purpose" (8). It is important to note that this definition is not applicable to government and public health data. It is crucial that public health data shared by the government should not be modifiable. Thus, in this paper, our definition of open data is a slight variation of the Open Definition. We define open data as data that can be freely used and shared by anyone for any purpose, under strict principles of privacy and confidentiality, when appropriate.

\section{Open government data}

Around the world, governments and quasi-governmental entities collect multiple categories of information, including on people, events, institutions, and the environment. With new information and communication technologies-especially the Internet-it is now easy to store this information in online databases. Access to most of these databases was often initially restricted to certain agencies of the government involved in collecting the data (9). However, governments around the world are now realizing the need to make this information available to the broader public for various reasons. Some of the reasons for making government data available, according to the information available on the Open Government Data website (10), are (a) transparency, which ensures that a government's activities are made known to the citizenry; (b) to release social and commercial value by encouraging innovative use of data by the citizens in ways that create additional usefulness; and (c) participatory governance, ensuring that citizens have access to data upon which government decisions are based.

Some initiatives measure government performance around the world regarding OGD.

The seven countries that ranked highest in the 2016 Global Open Data Index (GODI), which is run by the Open Knowledge Network, were Taiwan, Australia, Great Britain, France, Finland, Canada, and Norway. These seven countries were ranked from one to five, with two or more countries occupying the same position. Taiwan occupied the first position, followed by Australia and Great Britain sharing the second position. France is fourth, while Finland, Canada, and Norway all shared the fifth position (11).

Some of the data areas on which the GODI assesses openness are: national statistics, government budget, legislation, procurement tenders, elections results, national maps, weather forecasts, air quality, company registers, location datasets, water quality, land ownership, and government spending. Public health data is currently not included in this list.

It is noteworthy that among the top 20 countries with high OGD scores, based on the 2016 Global Open Data Index (GODI), 7 of them are in the Americas. These 7 countries are Canada, Brazil, Mexico, United States, Colombia, Argentina, and Uruguay.

Available studies already show the kinds of benefits that accrue when citizens utilize openly available government data. For example, Bătăgan demonstrated how open government data could enhance development in urban areas (12). In a similar study, a group of Finnish researchers looked at the Helsinki Region Infoshare open data service and concluded that "open data can significantly contribute to open government and transparency, citizen's engagement, better-informed decisions, innovative applications, better services, [and] new businesses and jobs" (13).

Government datasets are increasingly available on the Web, with open data standards over different platforms. In most cases, the datasets are in a nonproprietary format and are free of charge. Although such datasets can provide unlimited opportunities for decisionmakers, institutions, and researchers, their 
quality and usability are yet to be determined (14).

\section{Principles of "open" government data}

On 7-8 December 2007, 30 open government advocates met to develop a set of principles for open government data. Their objective was to create a more robust understanding of what "open" means and why government data is essential to democracy (15). They agreed that government information would be considered open if it complies with the principles listed in Table 1.

\section{Public health data}

As opposed to individual or personalized health, public health concentrates on the promotion and protection of the health of the entire population within a country, state, county, or city. Governments promote healthy lifestyles and conduct research on preventing injuries and on detecting and controlling infectious diseases. At times, governments in different countries-especially ones sharing a border-will agree and cooperate on public health efforts that promote the well-being of all their citizens (16-18).

We often distinguish between public and personal health, especially in relation to data sharing. However, it is important to note that public health data are usually obtained from individual or personal health data that have been anonymized in a required manner (19). Therefore, for effective public health data collection and management, there must be adequate and effective personal health data collection and management, especially for diseases that can result in major outbreaks. How do we effectively manage health data generated from a county, city, state, or country in order to help our decision-making in public health? How do we manage public health data among countries, especially ones sharing a geographical boundary? At what level do we have access to these datasets, and what are the requirements needed for using these data? Public health data that are available in the right format at the right time can help in making decisions that would prevent health-related catastrophes. Given that public health was not listed as part of the areas of open government data initiatives indicated in the Global Open Data Index (11), we wonder if there any issues that prevent making public health data open in some countries, or whether it was just an oversight by the team behind the initiative.

\section{METHODS}

\section{Literature search}

This literature review is driven by the following research questions:

1. What are the themes of publications about government open public health data?

2. What principles are considered important for open government public health data?

3. What factors get in the way of open government public health data?

4. How is government-released public health data being used in research studies?

5. How many publications are about or used government-released public health data from countries in the Americas?

We accessed scholarly articles from two databases: PubMed (http://www. ncbi.nlm.nih.gov/pubmed/) and
Scopus (http://www.scopus.com/). These articles focused on public health data openly released by governments and international organizations, such as the World Health Organization (WHO). Some of these openly released government data are accessible online through government websites, including the websites of international organizations such as WHO. We did not include scholarly articles about individual health data and those using data gathered by nongovernment entities. Our search prioritized journal articles and conference papers. We used the following search terms: [1] "open data" AND "public health" and [2] "open data" AND "health" AND "government."

We found 27 relevant scholarly articles in our search. Predominantly, these articles used open data from either the national government or local governments. Countries whose data were used in some of the articles include Australia, Brazil, India, Malaysia, Romania, South Korea, and the United States. One study used data from the World Health Organization. These countries, along with others listed in Table 2, have extensive open data guidelines published online.

\section{DISCUSSION}

One important element stressed in a few of the research articles is the concept of "linked data." Linked data is a term coined by Tim Berners-Lee (20) to describe best practices to publish and link structured data to other data available on the Web. Tilahun et al. (21) have asserted that publishing data as linked data will allow it to be understood by machines and discovered by search engines.

Linked data is not a new term in the health community. The Government of the United States has published some of

\section{TABLE 1. Principles of open government data as formulated by a group of open government advocates in 2007}

\begin{tabular}{|c|c|}
\hline Principle & Description \\
\hline Complete & All public data is made available. Public data is data that is not subject to valid privacy, security, or privilege limitations. \\
\hline Primary & Data is as collected at the source, with the highest possible level of granularity, not in aggregate or modified forms. \\
\hline Timely & Data is made available as quickly as necessary to preserve the value of the data. \\
\hline Accessible & Data is available to the widest range of users for the widest range of purposes. \\
\hline Machine processable & Data is reasonably structured to allow automated processing. \\
\hline Nondiscriminatory & Data is available to anyone, with no requirement of registration. \\
\hline Nonproprietary & Data is available in a format over which no entity has exclusive control. \\
\hline License-free & $\begin{array}{l}\text { Data is not subject to any copyright, patent, trademark, or trade secret regulation. Reasonable privacy, security, and privilege } \\
\text { restrictions may be allowed. }\end{array}$ \\
\hline
\end{tabular}

Source: Fiorenza (15). 
TABLE 2. Some country-specific open data guidelines

\begin{tabular}{ll}
\hline Country & Open data platform(s) \\
\hline Australia & Australian Bureau of Statistics (http://abs.gov.au/) \\
& Data SA (https://data.sa.gov.au/) \\
& PHIDU (http://publichealth.gov.au/data) \\
& Queensland Health (https://www.health.qld.gov.au/) \\
& Brazilian Government Open Data (http://dados.gov.br/) \\
Interagency Health Information Network (http://www.ripsa.org.br/) & Dados Recife (http://dados.recife.pe.gov.br/) \\
& Rio Open Data (http://data.rio/) \\
& Data Warehouse Web (http://www.saude.mt.gov.br/sistemas) \\
& Open Data Canada (http://open.canada.ca/en/open-data/) \\
Canada & Open Data Portal (http://datos.gob.cl/) \\
Chile & Open Data Colombia (https://datos.gov.co) \\
Colombia & Jamaica Open Data portal (http://data.gov.jm/) \\
Jamaica & Malaysian Government Open Data (http://www.data.gov.my/) \\
Malaysia & Open Data Mexico (https://datos.gob.mx/) \\
Mexico & Romanian Government Open Data (http://data.gov.ro/) \\
Romania & Korean Government Open Data (https://www.data.go.kr/) \\
South Korea & U.S. Open Government Data (https://www.data.gov/) \\
United States & HealthData.gov (http://www.healthdata.gov/) \\
& National Center for Health Statistics (https://www.cdc.gov/nchs/) \\
& OpenFDA (https://open.fda.gov/) \\
& OpenColorado (http://data.opencolorado.org/) \\
& Health Data NY (https://health.data.ny.gov/) \\
NYC OpenData (https://nycopendata.socrata.com/) & Open data catalog (https://catalogodatos.gub.uy/) \\
&
\end{tabular}

Source: Prepared by the authors from their study data.

its health datasets as linked data, according to Hendler et al. (22).

In fact, according to those authors, the most extensive use of linked data from Government of United States datasets has been by the health community. In Romania, Rinciog and Posea, two faculty members at the University Politehnica of Bucharest, have transformed the Romanian public health data, originally published in XLS format, to linked data (23). Linked data will enable quick access to similar and complementary data, especially during a public health emergency.

\section{Open data and public health}

There are many advantages or benefits associated with open data. These include transparency and democratic control, participation, self-empowerment, improved or new products and services, innovation, and new knowledge from combined data sources and patterns in large data volumes (24). Openly available public health data can bring about these benefits as well. For example, government entities can use public health data for better decision-making. Private entities can apply such data to create health-related products, scientists can utilize such data in their research work, and nongovernmental agencies can study such data to know more about areas of public health.

There are a few questions about openly available public health data. For example, what are the factors that may enhance or inhibit openly available public health data? How do we position ourselves to solve problems in such areas as policy and technical capability?

Vest and Issel (4) conducted a crosssectional analysis of organizational factors associated with gaps in data sharing between state health agencies and local health departments. They found that the proportion of local health departments experiencing a data sharing gap was $34.0 \%$ for childhood immunizations, $69.8 \%$ for vital records, and $81.8 \%$ for reportable conditions. They also reported that increased state health agency size and technological capacity reduced the likelihood of gaps.

In a similar study on the importance of adequate technical capability with regard to collecting and managing public that adopting technological innovations was important in enabling the quick and health data, Homan et al. (25) concluded effective collection of demographic and malaria data in western Kenya.

In an example relating to policy, Gasner et al. (5) presented a case study of data sharing between public health programs in New York City. They examined public health laws and agency policies for data sharing across surveillance programs for HIV, sexually transmitted diseases, tuberculosis, and viral hepatitis. The authors reported that recent changes to state laws provide greater opportunities for data sharing but that agency policies must be updated to allow increased data integration. This finding, for one city, would likely be even more important when considering entities spread across larger geographical areas.

\section{Key policy issues}

Our discussion so far has presented evidence supporting the open data movement around the world. However, to have greater benefits from open access within the public health sector will require conscientious efforts addressing many of the issues that are pertinent and peculiar to that sector. As shown in Figure 1, effective policy formulation for open public health data must deal with four fundamental concerns: benefits, risks, examples, and attributes. These four issues are key concerns for us after having considered some of the concepts discussed in the extant literature on open health data. We note that it is important to articulate the potential benefits of open data, potential risks associated with it, examples of data that should be made open, and the attributes of such data.

In terms of potential benefits, it is essential to highlight the importance of sharing health data within a public policy supporting open public health data. The public needs to be aware, without any ambiguity, of the potential benefits as they relate to subgroups, and to the overall population within a given city, state, or country, or even across countries. Those benefits can give credence to the content of such public policy.

Another issue of potential concern is risks associated with data sharing. It is important as part of a public policy to indicate potential risks that may be associated with making any type of public health data open. It is also important to identify ways to limit such risks. Possible benefits need to be weighed against any potential risks. 
FIGURE 1. Key policy issues with open public health data

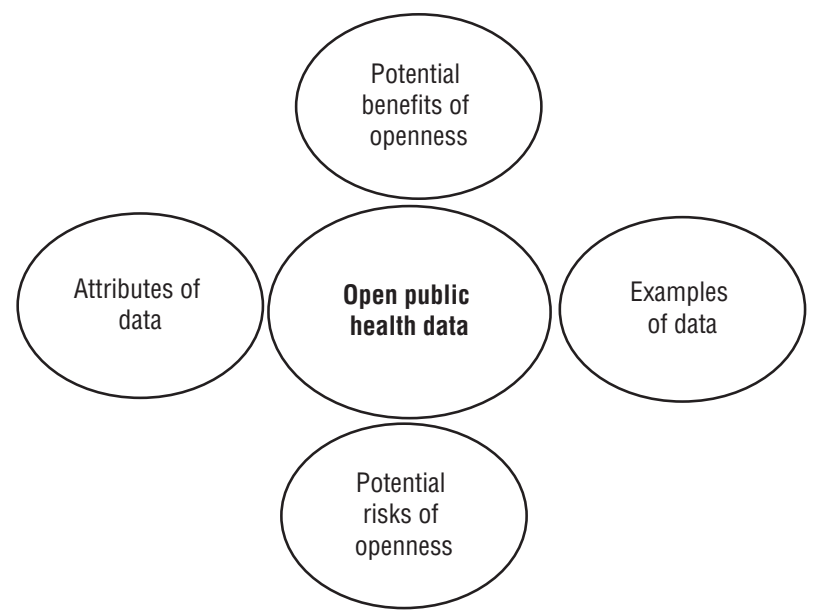

Source: Prepared by the authors from previous studies, including Crouch and Wilson (26).

Additionally, mention must be made of the examples of the specific types of data that would constitute public health data and thereby qualify to be made open to a larger, public audience.

The attributes of such examples of health data must also be adequately stated. We know that it is the collection of individual health data that is aggregated as public health data. There must be guidelines that will prevent the release of data attributes that can be used to directly link publicly available health data to specific individuals.

\section{Open data in the Americas}

Any discussion of open data in the Americas needs to consider the issue of open access. In an April 2014 panel discussion at Columbia University in New York City, open access initiatives across the Americas were examined (27). One of the panelists was Heather Joseph, the executive director of the Scholarly Publishing and Academic Resources Coalition (SPARC). She provided an overview of the policy framework in the United States regarding open access to scholarly articles and data that are the output of government-sponsored projects, through such agencies as the National Institutes of Health (NIH). She said that the drivers for open access policies in the United States include the fact that, on a yearly basis, the federal Government's investment in basic and applied scientific research is around US\$ 60 billion. Spending such huge public sums on research ought to help generate new ideas, make new discoveries, and enhance our understanding of the world. These benefits are only possible when there is access to and utilization of the results of this scientific research. Awareness of that great potential has led the United States Government to develop open access policies contained in such documents as the Office of Management and Budget (OMB) Circular No. A-130 (1).

In that April 2014 panel, Joseph also said that, in conscientious efforts over the years, the Congress of the United States has endorsed policy statements supporting open access to governmentfunded research work at different levels. Over time, the language in those documents has shifted from encouraging scholars to deposit their government-funded results (articles plus data) on open platforms within a given period to mandating them to do so as a condition for financial support.

Apart from the OMB Circular No. A-130, some of the documents embodying support for open access in the United States include the Copyright Act (17 U.S.C. 105), the Freedom of Information Act (FOIA), the Paperwork Reduction Act, the Electronic Freedom of Information Act Amendments of 1996, and the Government Paperwork Elimination Act.

Joseph also noted that the first agency of the United States Government to implement an open access policy was the NIH. The research community could benefit from understanding how the $\mathrm{NIH}$ push for openness has affected public health data sharing at large. Based on the NIH open access policy, two questions the authors of this paper and other scholars may want to investigate are: 1) How open is health data that could help make effective public health decisions in the United States? 2) Is the current policy framework strong enough to cover public health data sharing, especially during public health emergencies?

Another panelist at that April 2014 session was Dominique Babini, the open access program coordinator of the Latin American Council on Social Sciences (CLACSO). She pointed to a number of Latin American countries whose legislatures have approved open access policies that are similar to those in the United States, requiring the creation of open access digital repositories for governmentfunded research results. Brazil did that in 2011, Argentina and Peru did so in 2013, and Mexico followed in 2014.

According to a report from the United Nations Educational, Scientific and Cultural Organization (UNESCO) (28), among Latin American countries, Brazil has the largest number of institutional open access policies (in total, 16), trailed by Peru (6), Argentina (4), Venezuela (4), Colombia (3), Mexico (3), and Bolivia (1).

In addition to the efforts on open access policies being made in individual Latin American countries, there are various major regional projects and initiatives. According to UNESCO (28), one of these is the Scientific Electronic Library Online (SciELO). SciELO is a cooperative, decentralized platform for electronic publishing of scientific journals, with national focal points in 15 countries, mainly in Latin America. Other regional initiatives include the Red de Revistas Científicas de América Latina y el Caribe, España y Portugal (Redalyc); Regional Cooperative Online Information System for Scholarly Journals from Latin America, the Caribbean, Spain and Portugal (Latindex); Biblioteca Virtual en Salud (Virtual Health Library) (BVS); LatinAmerican Citations in Social Sciences and Humanities (CLASE); Index of Latin-American Journals in Science (PERIODICA); Agricultural Information and Documentation Service of the Americas (SIDALC); and Digital Library of the Caribbean (dLOC).

Given these many regional and subregional efforts on open access, sharing public health data in the Americas should be less of a challenge than some persons might think. This optimism is buttressed 
by initiatives around the world that measure government performance on open government data, which show that many countries in the Americas have adopted open access policies (11).

The central challenge in relation to open data on public health in the Americas is that of developing regional frameworks that can be adopted or adapted by each country through national or subnational policies. Such frameworks must be easy to apply and to fit into the needs of each country, as well as those of the region overall. To help achieve this, teams of experts must work with individual countries in sharing ideas and lessons learned and in focusing on common attributes that can help resolve complex decision-making issues.

\section{Open data in the world}

Government data repositories are unequally spread around the world, and the health information in them is not always open and available online, according to a 2016 observational study (29). While there are international mandates and commitments on collecting health data, current open health data portals use a variety of formats. These portals mainly contain data on new diseases, directories of health institutions, and detailed descriptions of regulatory agencies to the results of federally funded research. Available from: https://www. whitehouse.gov/blog/2013/02/22/expanding-public-access-results-federallyfunded-research Accessed on 1 August 2016.

2. Sheehan J. Increasing access to the results of federally funded science. Available from: https:/ /obamawhitehouse.archives. gov/blog/2016/02/22/increasing-access-results-federally-funded-science Accessed on 28 February 2018.

3. Carney TJ, Weber DJ. Public health intelligence: learning from the Ebola crisis. Am J Public Health. 2015;105(9):1740-4. doi: 10.2105/AJPH.2015.302771

4. Vest JR, Issel LM. Factors related to public health data sharing between local and state health departments. BMC Health Serv Res. 2014;49(1pt2):373-91. doi: 10.1111/1475-6773.12138

5. Gasner MR, Fuld J, Ann D, Jay KV. Legal and policy barriers to sharing data between public health programs in New York City: a case study. Am J Public Health. 2014;104(6):993-7. that collect official data. However, there is a lack of standardization and interoperability among countries and among portals and repositories. Further, while our study found examples of exceptionally well-organized national open data portals, fewer than one-third of the world's countries had principled, organized portals set up to systematically share open data.

\section{Limitations}

This review is based on the available secondary information. A further analysis of primary data related to current initiatives that have not been made public may provide further evidence of policies that are not publicly available.

\section{CONCLUSIONS}

Open data measurement is still a new and experimental field. A national data governance strategy could be a critical tool to improve health analysis and to forecast possible scenarios (30). In this paper, we have identified some current, functional open data policies in many countries, including in North America and South America. Our analysis has further shown that there are currently no articulated policy guidelines for the collection and management of public health

\section{REFERENCES}

6. Nguyen LH. A public health response to data interoperability to prevent child maltreatment. Am J Public Health. 2014;104(11): 2043-8.

7. Project Open Data. Principles. Available from: https://project-open-data.cio.gov/ principles/ Accessed on 22 August 2016.

8. Open Definition. The Open Definition. Available from: http://opendefinition. org/ Accessed on 10 August 2016.

9. Samuel NO. Research support and open access: notes from Nigeria. Afr J Lib Arch Inf Sci. 2016;26(1):17-29.

10. Open Government Data. Welcome to Open Government Data. Available from: http: / / opengovernmentdata.org / Accessed on 6 July 2016.

11. Open Knowledge International. Global Open Data Index; 2015. Available from: http:/ / 2015.index.okfn.org/place / Accessed on 29 January 2018.

12. Bătăgan L. The role of open government data in urban areas development. Inform Econ. 2014;18(2):80-7. doi.org/10.12948/ issn14531305/18.2.2014.08

13. Jaakola A, Kekkonen H, Lahti T, Manninen A. Open data, open cities: experiences data in the Americas. Any national data governance strategy must address potential benefits, potential risks, examples of data that could be shared, and the attributes of such data.

We hope that the information provided in this article will support countries and health-related organizations as they develop national strategies on interconnected and interoperable open health data portals, especially within the context of national public health strategies and in line with other open government initiatives.

Acknowledgments. We thank the students of the University of Illinois at Urbana-Champaign who participated in the Global Health Informatics class in the spring of 2016. We presented initial ideas there that we later expanded on in this paper, and the students' comments and questions helped us clarify our views. We are also grateful to the anonymous reviewers for questions and observations that assisted us in refining the paper.

\section{Conflicts of interest. None declared.}

Disclaimer. Authors hold sole responsibility for the views expressed in the manuscript, which may not necessarily reflect the opinion or policy of the RPSP/ PAJPH or PAHO. from the Helsinki Metropolitan Area. Case Helsinki Region Infoshare www.hri.fi. Stat J IAOS. 2015;31(1):117-22. http://doi. org/10.3233/SJI-150873

14. Martin EG, Law J, Ran W, Helbig N, Birkhead GS. Evaluating the quality and usability of open data for public health research: a systematic review of data offerings on 3 open data platforms. J Public Health Manag Pract. 2017;23(4): e5-e13.

15. Fiorenza P. A brief history of open data and GIS. Available from https://www. govloop.com/a-brief-history-of-opendata-and-gis/ Accessed on 28 February 2018.

16. American Public Health Association. What is public health? Available from: https: / /www.apha.org/what-is-publichealth Accessed on 6 July 2016.

17. CDC Foundation. What is public health? Available from http://www.cdcfoundation.org/content/what-public-health Accessed on 6 July 2016.

18. HealthData.gov. Welcome to HealthData. gov. Available from http://www.healthdata.gov/ Accessed on 6 July 2016. 
19. Richardson V, Milam S, Chrysler D. Is sharing de-identified data legal? The state of public health confidentiality laws and their interplay with statistical disclosure limitation techniques. J Law Med Ethics. 2015;43:83-6. http://doi.org/10.1111/jlme. 12224.

20. Berners-Lee T. Linked data. Available from: https:/ /www.w3.org/DesignIssues/ LinkedData.html Accessed on 19 September 2016.

21. Tilahun B, Kauppinen T, Keßler C, Fritz, F. Design and development of a linked open data-based health information representation and visualization system: potentials and preliminary evaluation. J Med Internet Res. 2014;16(10):e31. http://dx. doi.org/10.2196/medinform.3531

22. Hendler J, Holm J, Musialek C, Thomas G. US government linked open data: Semantic. data.gov. IEEE Intell Syst. 2012;27(3):25-31. http:/ / dx.doi.org/10.1109/MIS. 2012.27

23. Rinciog O, Posea V. Publishing Romanian public health data as Linked Open Data.
Paper presented at: 2015 E-Health and Bioengineering Conference (EHB); 2015 Oct 19-21, Iaúi; Romania.

24. Open Knowledge International. Why open data? Available from: http://opendatahandbook.org/guide/en/why-opendata/ Accessed 12 July 2016.

25. Homan T, Di Pasquale A, Kiche I, Onoka $\mathrm{K}$, Hiscox A, Mweresa C, et al. Innovative tools and OpenHDS for health and demographic surveillance on Rusinga Island, Kenya. BMC Res Notes. 2015;8(1):397. http: / / doi.org/10.1186/s13104-0151373-8

26. Crouch EAC, Wilson R. Risk/benefit analysis. Available from: https://www.osti. gov/biblio/5557457 Accessed on 28 February 2018.

27. Joseph H, Sinatra M, Babini D, Graham PM. Open access in the Americas [mp4 recording]. Available from: http://dx.doi. org/10.7916/D8736P0S Accessed 28 February 2018.

28. United Nations Educational, Scientific and Cultural Organization, Global Open
Access Portal. Latin America and the Caribbean. Available from: http://www. unesco.org/new/en/communicationand-information/portals-and-platforms / goap/access-by-region/latin-americaand-the-caribbean/ Accessed on 1 March 2018.

29. Greenberg CJ, Narang S. World Health Organization member states and open health data: an observational study. Epidemiol Biostat Public Health. 2016; 13(3).

30. Global Open Data Index. Open Data Index 2015: civil society audit of the state of open data. Available from: http://2015.index. okfn.org/about/ Accessed 15 February 2018.

Manuscript received on 30 September 2016. Revised version accepted for publication on 8 February 2017.
RESUMEN

\section{Datos abiertos y salud pública}

Palabras clave
Este artículo ofrece un panorama de la intersección entre los datos abiertos y la salud pública al definir en primer lugar qué son los datos gubernamentales abiertos, los datos sobre salud pública y otros conceptos fundamentales y términos pertinentes. Hay percepciones dispares sobre la premura y la importancia de la apertura de los datos sobre salud pública. Se ha establecido que los brotes de ciertas enfermedades, como las epidemias por los virus del Ébola y del Zika, demuestran la necesidad de que los países elaboren un marco que oriente la gestión de los datos sobre salud pública. Dicho marco debe garantizar que los datos recopilados durante las emergencias de salud pública sean accesibles para las autoridades competentes y en una forma que contribuya a la toma oportuna de decisiones durante estas crisis de salud pública. En este artículo, destacamos las políticas de datos abiertos existentes en diversos países, incluidos varios de la Región de las Américas. Nuestro análisis muestra que actualmente en muchos países no hay directrices articuladas de políticas públicas para la recopilación y gestión de los datos sobre salud pública, en especial en América Latina. Proponemos que toda estrategia nacional de gobernanza relativa a los datos debe abordar los posibles riesgos y beneficios, ejemplos de los datos que podrían compartirse y los atributos de tales datos. Por último, subrayamos que el interés fundamental en la Región de las Américas debe ser la creación de marcos regionales para datos abiertos sobre salud pública que cada país pueda adoptar o adaptar mediante las políticas y estrategias nacionales o subnacionales apropiadas.

Sistemas de información; fuentes de datos; salud pública; sistemas de salud; confidencialidad. 
RESUMO Este artigo expõe um panorama da interseção entre dados abertos e saúde pública, começando por definir o que são dados abertos do governo, dados de saúde pública e outros conceitos fundamentais e terminologias relevantes. Existem distintas percep-

Dados abertos e saúde pública

Palavras-chave ções quanto à premência e à importância da abertura de dados de saúde pública. Reconhecidamente, os surtos de doenças, como os ocorridos nas epidemias do vírus Ebola e vírus zika, apontam para a necessidade de os países desenvolverem uma estrutura para direcionar o gerenciamento dos dados de saúde pública. Esta estrutura deve servir para garantir que os dados coletados nas emergências de saúde pública estejam acessíveis às autoridades cabíveis em uma forma que possa subsidiar a tomada de decisão oportuna durante tais crises de saúde pública. No artigo, destacam-se as políticas de dados abertos de diversos muitos países, inclusive dos países na Região das Américas. Nossa análise demonstra que vários países, sobretudo na América Latina, não possuem diretrizes claramente definidas de políticas para a coleta e o gerenciamento de dados de saúde pública. Recomendamos que qualquer estratégia nacional de governança de dados nacionais precisa contemplar os possíveis benefícios e riscos, explicitar os dados a ser compartilhados assim como descrever os atributos de tais dados. Por fim, salientamos que a principal preocupação nas Américas deve ser o desenvolvimento de estruturas regionais para dados abertos em saúde pública que possam ser postas em prática ou adaptadas por cada país como parte de estratégias e políticas nacionais ou subnacionais adequadas.

Sistemas de informação; fontes de dados; saúde pública; sistemas de saúde; confidencialidade. 